\title{
PENDEKATAN IJBARI DALAM STUDI AL-QUR'AN
}

\author{
Zaglul Fitrian Djalal \\ STAIN Pamekasan \\ Email:al_jifun@gmail.com
}

\begin{abstract}
Abstrak:
Al-Qur'an secara teks tidak berubah, tetapi penafsiran atas teks, selalu berubah, sesuai dengan konteks ruang dan waktu manusia. Karenanya, al-Qur'an selalu membuka diri untuk dianalisis, dipersepsi dan diinterpretasikan (ditafsirkan) dengan berbagai alat, metode, dan pendekatan untuk menguak isi sejatinya. Aneka metode dan tafsir diajukan sebagai jalan untuk membedah makna terdalam dari al-Qur'an itu. Salah satu pendekatan dalam studi alQur'an adalah pendekatan ijbäri (eksperimen). Pendekatan dengan riset ijbäri ini diartikan sebagai penelitian eksperimen. Penelitian ini mengambil alam fisika sebagai objek penelitiannya; langit, bumi, air, tubuh manusia, dan lain-lain. Penelitian eksperimental inilah yang membuat Islam maju dan memimpin dunia pada masa keemasannya.
\end{abstract}

Kata Kunci: ijbari, Al-Qur'an

\begin{abstract}
:
The Qur'an is textually unchanged, but the interpretation of the text, constantly changing, corresponds to the context of human space and time. Therefore, the Qur'an always opens itself to be analyzed, perceived and interpreted (interpreted) with various tools, methods, and approaches to uncover its true content. Various methods and interpretations are proposed as a way to dissect the deepest meaning of the Qur'an. One approach in the study of the Qur'an is the ijbārī (experimental) approach. This approach with ijbāri research is interpreted as experimental research. This research takes the nature of physics as the object of its research; sky, earth, water, human body, and others. This experimental study has led Islam to advance and lead the world in its heyday.
\end{abstract}

Keywords: ijbäri, Al-Qur'an 


\section{Pendahuluan}

Tafsir memiliki sejarah panjang, berlangsung melalui berbagai tahap dan kurun waktu sehingga mencapai bentuknya seperti dapat disaksikan sekarang ini. ${ }^{1}$ Seiring dengan perkembangan tafsir itu, para ulama mulai mengembangkan arah yang berbeda-beda dalam menafsirkan al-Qur'an. Pemahaman dan penafsiran terhadap alQur'an, selain sebagai produk juga sebagai proses di mana antara teks, penafsir dan realitas selalu berhubungan. Hal ini dapat dilihat dari metode, corak, karakteristik dan kecenderungan produk tafsir yang selalu berkembang. Bahkan, aspek paradigma dan epistimologi untuk mendekati al-Qur'an juga selalu mengalami perkembangan dan pergeseran. ${ }^{2}$ Pada titik ini, tafsir dapat dipahami sebagai salah satu bentuk cerminan produk pemikiran dan peradaban manusia secara umum, karena ia juga selalu mengalami perkembangan dan dipengaruhi dinamika peradaban manusia.

Al-Qur'an secara teks tidak berubah, tetapi penafsiran atas teks, selalu berubah, sesuai dengan konteks ruang dan waktu manusia. Karenanya, al-Qur'an selalu membuka diri untuk dianalisis, dipersepsi dan diinterpretasikan (ditafsirkan) dengan berbagai alat, metode, dan pendekatan untuk menguak isi sejatinya. Aneka metode dan tafsir diajukan sebagai jalan untuk membedah makna terdalam dari al-Qur'an itu.

Disadari bahwa al-Qur'an tidaklah di turunkan dalam rentangan waktu dan kondisi yang hampa kultural. Demikian pula, tafsiran-tafsiran yang diberikan oleh para mufassirin pada masanya terdahulu tidak terlepas dari konteks zamannya. Penafsiran mufassir sebelum abad ke-20 tidaklah memiliki konsepsi-konsepsi kebutuhan abad ke-20. Penafsiran yang sudah ada mungkin menyimpang atau bisa jadi telah menjadi usang.

Perbedaan-perbedaan pendapat pada masa lampau terikat atau terpengaruh oleh berbagai peristiwa sejarah. Kini, situasinya sudah berubah. Perbedaan pendapat yang berakar pada kasuskasus masa lampau haruslah ditinggalkan, karena kita sekarang sudah berhadapan dengan masalah-masalah yang berbeda. Oleh karena itu, ajakan untuk kembali kepada al-Qur'an secara eksplisit dan implisit menghendaki tafsiran-tafsiran baru yang logis dan realistis.

1 Rif'at Syauqi Nawawi, Rasionalitas Tafsir Muhammad Abduh (Jakarta: Paramadina, 2002), 91.

2 Abdul Mustaqim, Pergeseran Epistemologi Tafsir (Yogyakarta: Pustaka Pelajar, 2008), 33. 
Penafsiran baru yang dimaksud merupakan perasaan adanya keperluan untuk melakukan upaya-upaya pembaruan dan penyesuaian dalam penafsiran al-Qur'an dengan menggunakan pendekatan-pendekatan baru yang lebih baik. Usaha ini merupakan upaya memahami ayat-ayat al-Qur'an dengan konteksnya, yaitu situasi dan permasalahan masa kini.

Dengan munculnya berbagai ilmu pengetahuan dan semakin meningkatnya ilmu pengetahuan tersebut, baik ilmu alam maupun ilmu sosial menuntut kita agar memahami dan menafsirkan alQur'an tidak hanya harfiah saja, tetapi haruslah dengan cara pendekatan teoritis. Objek pengamatan yang sama bisa tampak berbeda, karna perbedaan cara penglihatan atau perbedaan pendekatan teori yang kita pakai. Hal ini bisa dimengerti sebab teori tersebut akan membentuk realitas yang diamati. Demikian halnya ketika kita memahami dan menafsirkan al-Qur'an yang dianggap sebagai realitas, sebagai wujud ketentuan-ketentuan tuhan yang pasti dan jelas tertulis.

Indikasi diatas menunjukkan bahwa penafsiran akan berbeda apabila pendekatan dan teori yang digunakan berbeda. Hasil penafsiran menggunakan paradigma ilmiah tidaklah sama dengan hasil penafsiran secara harfiah. Untuk itu, penafsiran al-Qur'an yang banyak melibatkan disiplin ilmu pengetahuan akan menghasilkan teori-teori baru dari realitas al-Qur'an. Dengan realitas ini, objek pengamatan yang terdapat dalam masyarakat dapat diamati secara lebih konstektual dan menghasilkan penjelasan-penjelasan yang lebih bisa diterima, baik yang berhubungan dengan peristiwa sejarah masa lampau maupun keadaan sekarang.

Sejalan dengan kebutuhan umat Islam untuk mengetahui seluruh segi kandungan al-Qur'an serta intensitas perhatian para ulama terhadap tafsir al-Qur'an, maka tafsir al-Qur'an terus berkembang sampai sekarang. Dari sinilah, para mufasirin menemukan berbagai macam pendekatan tafsir. Masing-masing dari pendekatan tafsir mempunyai keistimewaan dan sekaligus kelemahan. Pendekatan yang akan dipakai oleh para mufasir tergantung kepada apa yang hendak diketahui atau dicapainya. Salah satu pendekatan dalam studi al-Qur'an adalah pendekatan ijbäri.

\section{Definisi Pendekatan Ijbārí}

Salah satu pendekatan dalam studi al-Qur'an adalah pendekatan ijbari (eksperimen). Pendekatan dengan riset ijbäri ini diartikan sebagai penelitian eksperimen. Penelitian ini mengambil 
alam fisika sebagai objek penelitiannya; langit, bumi, air, tubuh manusia, dan lain-lain. Penelitian eksperimental inilah yang membuat Islam maju dan memimpin dunia pada masa keemasannya. Para tokoh Islam seperti Ibn Sinā di bidang kedokteran dan al-Khawarizmi di bidang optik adalah di antara ilmuwan riset ijbäri ini. ${ }^{3}$

Berkenaan dengan pendekatan ini, M. Quraish Shihab mengemukakan pandangannya bahwa, apa yang dipersembahkan para ahli dari berbagai disiplin ilmu, sangat bervariasi dari kebenarannya. Seseorang bahkan tidak dapat mengatas namakan al-Qur'an dalam kaitan dengan pendapatnya, jika pendapat tadi melebihi kandungan redaksi ayat-ayat. Tetapi hal ini bukan berarti seseorang dihalangi untuk memahami suatu ayat sesuai dengan perkembangan ilmu pengetahuan. Hanya selama pemahaman tersebut sejalan dengan prinsip-prinsip ilmu tafsir yang telah disepakati. ${ }^{4}$

\section{Pendekatan Ijbāîi dalam Studi Al-Qur'an}

Bila diamati dalam al-Qur'an, dapat ditemukan dua bentuk realitas, yaitu realitas yang dapat didekati dengan pengalaman empiris melalui eksperimen dan observasi dan realitas yang berada di luar jangkauan pengalaman indrawi ${ }^{5}$.

Realitas yang dapat didekati dengan pengalaman empiris memiliki akar teologis dengan sinyalemen al-Qur'an tentang ayatayat kauniyah dan eksistensi individu dalam masyarakat. Untuk menjabarkan sinyalemen tersebut dan memahami realitas ini, penalaran mempunyai posisi yang sangat strategis dan menentukan. Di pihak lain, ada realitas yang berada di luar pengalaman manusia yaitu bagian metafisik yang lebih memerlukan pendekatan iman. Untuk realitas ini, al-Qur'an menggunakan ungkapan al-ghảib. ${ }^{6}$ Muhammad Assad mendefinisikan realitas metafisik sebagai realitas yang berada di luar persepsi metafisik

3 http://hadiyan.wordpress.com/2011/10/18/lima-riset-tradisi-keilmuanislam/. Diakses pada tanggal 14 Juni 2014.

${ }^{4}$ M. Quraish Shihab, Membumikan Al-Qur'an Fungsi dan Peran Wahyu dalam Kehidupan Masyarakat (Bandung: Penerbit Mizan, 1994), 107-109.

5 Ahmad Syafi'ie Ma'arif, "Posisi Sentral Al-Qur'an dalam Studi Islam", dalam Metodologi Penelitian Agama, ed. Taufik Abdullah dan M. Rusli Karim (Yogyakarta: PT. Wacana Yogya, 1989), 129.

${ }^{6}$ Ibid. 
sebagai realitas yang berada di luar persepsi manusia dan tidak dapat dibuktikan melalui observasi ilmiah ${ }^{7}$.

Memahami ayat-ayat yang berhubungan dengan kauniyah dan eksistensi manusia dalam masyarakat tidaklah cukup dengan memerhatikan tafsiran teksnya secara harfiah, tetapi haruslah melibatkan banyak disiplin ilmu, terutama ilmu alam dan ilmu sosial. Di samping itu, seorang penafsir harus memerhatikan konteks ayatnya, yaitu situasi dan kondisi yang melingkupinya dan keadaan sosial kulturalnya. Menurut M. Quraish Shihab, paling tidak haruslah diperhatikan pengetahuan bahasanya, konteks antara kata-kata ayat dan sifat penemuan ilmiah ${ }^{8}$.

Bertitik tolak dari realitas al-Qur'an sebagai realitas yang dapat didekati melalui pengalaman empiris sejalan dengan sinyalemen al-Qur'an tentang ayat-ayat kauniyah dan eksistensi manusia dalam masyarakat, maka sesungguhnya tepat apabila ayatayat al-Qur'an ditafsirkan secara ilmiah dan memadukannya secara relevansif dengan perkembangan ilmu pengetahuan melalui pendekatan analitis interdisipliner dan kontekstual.

Pada hakikatnya al-Qur'an memperlakukan seluruh apa yang diciptakan sebagai tanda (sign/ayat). Hal ini termasuk alam semesta dan semua yang ada di dalamnya. Meskipun al-Qur'an memberikan penjelasan yang sangat spesifik mengenai penciptaan kosmos, ia tidak memberitahu kita dengan apa dibuatnya atau kapan. Selain itu, penting untuk diingat bahwa alam semesta menurut al-Qur'an bukan hanya materi fisik yang terdiri dari bintang-bintang, planet dan entitas fisik lainnya, tetapi juga mencakup kosmos spiritual yang dihuni oleh entitas nonfisik. Kosmos nonfisik itu terdiri dari tingkat-tingkat eksistensi yang tak terhitung dan jauh lebih unggul dari alam fisik yang menempati posisi relatif rendah dalam tingkat eksistensi.

\section{Aplikasi Pendekatan Ijbārỉ dalam Tafsir Al-Qur'an}

Dalam perspektif al-Quran tentang penciptaan alam fisik dapat diringkas sebagai berikut: alam semesta diciptakan Tuhan untuk suatu tujuan. Setelah menciptakan alam semesta dan semua yang terkandung di dalamnya, Tuhan tidak meninggalkannya, karena kenyataannya seluruh ciptaan selalu membutuhkan Tuhan dan tanpa cinta-Nya kosmos tidak bisa eksis. Pada saat sebelum

\footnotetext{
${ }^{7}$ Muhammad Assad, The Message of the Qur'an (Gibraltar: Dār al-Maktab, 1980), 4.

${ }^{8}$ M. Quraish Shihab, Membumikan Al-Qur'an 105.
} 
mewujudnya suatu momen, kepastian pengetahuan tetap berada pada Tuhan. Segala sesuatu yang ada di dunia akan binasa. Hal ini akan diikuti dengan kebangkitan dan kehidupan jenis baru di bawah seperangkat hukum yang sama sekali baru.

\section{Kajian Al-Ard (bumi) dalam Al-Qur'an}

Kata الأرض (al-ard) dalam al-Qur'an disebutkan sebanyak 461 kali, baik dalam ungkapan singular (مفرد) - ini lebih dominan maupun plural (مع). Dalam bahasa Arab, term ard (أرض) berarti bumi dengan bentuk pluralnya adalah araduna (أرضون) atau aradiy (أرضاض). Menurut Ibn Zakariyah, term ألمموة - الراء yang terdiri atas tiga huruf - الضزمة (1) الزياد (1) memiliki tiga makna dasar, yaitu rileks; (2) إعالة berarti tinggi. ${ }^{10}$ Dari ketiga makna ini, maka dapat saja dikatakan bahwa bumi itu memiliki sifat yang "rileks" karena diartikan sebagai "tempat bertumpuh". Boleh juga dikatakan "gemetar" disebabkan kegoncangan yang sering terjadi di bumi. Juga diartikan "tinggi" dikarenakan gunung-gunung yang menjulang di permukaan bumi.

Terkait pengertian di atas, dalam Kamus Umum Bahasa Indonesia ditemukan beberapa batasan umum tentang bumi. Pertama: tanah, ${ }^{11}$ karena unsur dominan yang tampak di bumi adalah tanah. Kedua: dunia,12 karena bumi mengambil posisi di dunia. Ketiga: bola, ${ }^{13}$ sebab bentuk bumi adalah bundar.

Selanjutnya dalam Ensiklopedia Al-Qur'an dikatakan bahwa bumi yang kita diami ini terdiri dari air laut dan darat, lebih kurang $71 \%$ lautan. Jaraknya dari matahari $93.000 .000 \mathrm{ml}$ dan bumi termasuk salah satu dari sembilan planet beredar mengelilingi matahari. ${ }^{14}$ Sedangkan menurut sains, bumi dikenal sebagai salah satu tata surya atau planet yang berputar pada sumbunya secara

9 Ahmad Warson Munawwir, Kamus Al-Munawwir Arab Indonesia Terlengkap (Yogyakarta: Pustaka Pesantren, 1984), 20. Lihat juga Hussin al-Habsyi, Kamus al-Kauthar Lengkap Arab-Indonesia, Cet. III (Surabaya: Yayasan Pesantren, t.th.), 279.

${ }^{10}$ Abū Husayn Ahmmad Ibn Fāris Ibn Zakariyah, Mu'jam Maqāyīs al-Lughah, Cet. II, Vol. II (Kairo: Musțafā al-Bābȳ al-Halaby, 1971), 79.

11 W.J.S. Poerwadarminta, Kamus Umum Bahasa Indonesia, Cet. I (Jakarta: Balai Pustaka, 1984), 165.

12 Ibid.

13 Ibid.

14 Fachruddin HS., Ensiklopedia Al-Qura'n, Cet. I, Vol. I (Jakarta: Rineka Cipta, 1952), 246. 
sistematis. $^{15}$ Pergantian siang dan malam di bumi melalui pergerakan matahari yang membawa cahaya yang mengelilinginya. Jika bumi berhadapan dengan matahari tanpa dihalangi planet lain, maka terjadilah siang, demikian pula sebaliknya.

Dengan berputarnya bumi dan terjadinya siang dan malam, manusia dapat mengetahui bilangan hari. Di samping bumi berputar mengelilingi sumbunya, bumi juga berputar mengelilingi matahari. Satu kali putaran selama 365 1/2 hari, maka terhitung sebagai satu Tahun Shamsiyah menurut peredaran bumi mengelilingi matahari. Sedangkan Tahun Qamariyah dihitung menurut peredaran bulan mengelilingi bumi dalam setahun dengan dua kali putaran.

Dewasa ini, daftar literatur yang membahas masalah ard dengan merujuk kepada al-Qur'an cukup banyak. Di antaranya, AlQur'an Tentang Alam Semesta karya Muhammad Jamaluddin alFandy yang memfokuskan inti pembahasannya pada firman Allah SWT QS. Yunus (10): 24:

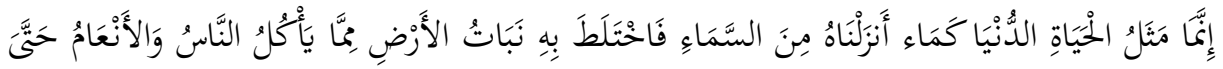

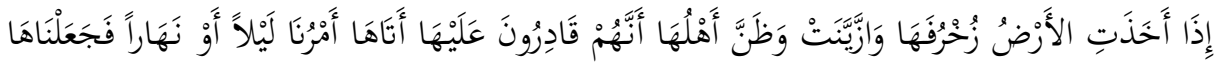

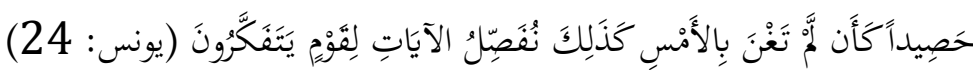

"Sesungguhnya perumpamaan kehidupan duniawi itu, adalah seperti air (hujan) yang Kami turunkan dan langit, lalu tumbuhlah dengan suburnya karena air itu tanam-tanaman bumi, di antaranya ada yang dimakan manusia dan binatang ternak. Hingga apabila bumi itu telah sempurna keindahannya, dan memakai (pula) perhiasannya, dan pemilik-permliknya mengira bahwa mereka pasti menguasasinya, tiba-tiba datanglah kepadanya azab Kami di waktu malam atau siang, lalu Kami jadikan (tanam-tanamannya) laksana tanam-tanaman yang sudah disabit, seakan-akan belum pernah tumbuh kemarin. Demikianlah Kami menjelaskan tandatanda kekuasaan (Kami) kepada orang-orang berfikir". ${ }^{16}$

Al-Fandy dalam menginterpretasikan ayat di atas menyimpulkan bahwa masa depan umat manusia di bumi adalah gambaran yang paling benar yang diberikan sebelumnya mengenai

15 Muhammad Ramli, Ilmu Alamiah Dasar "Diktat" (Ujung Pandang: Fakultas Ushuluddin, 1993), 6.

16 Departemen Agama RI, Al-Qur'an dan Terjemahnya (Semarang: Toha Putra, 1983), 310. 
dimulainya peradaban di berbagai penjuru dunia. Lebih lanjut beliau mengemukakan bahwa ayat di atas memberikan gambaran kepada kita tentang kekuatan ilmu pengetahuan yang luar biasa, sehingga manusia dapat menguasai ruang angkasa, menaklukkan sungai dan lautan serta menghancurkan bukit-bukit besar dan kecil. ${ }^{17}$

Batasan al-ard dalam konteks kekinian telah berkembang maknanya. Pada akhirnya perkembangan term al-ard dalam alQur'an dewasa ini diidentikkan dengan tiga konsep, yaitu dunia (دنيا), tanah (تراب) dan tempat tinggal manusia(دكن). 18 (سكن)

Dunia (دنيا)

Penyebutan kata دنيا (dunia) dalam al-Qur'an terdapat 112 kali. ${ }^{19}$ Kata دنيا dalam bahasa Arab artinya dekat ${ }^{20}$ dan berarti hina. ${ }^{21}$ Dalam Lisân al-Arab, kata دنيا berasal dari دنا - دنو - دناوة semakna dengan قرب yang berarti dekat. Dinamakan dunia karena dekat posisinya dengan tempat kita bahkan kita inipun berada dalam dekapan dunia. Selain itu dunia dikenal juga dengan nama kehidupan yang dijalani sekarang karena jauh dari akhirat. ${ }^{22}$

Ungkapan "dunia" sebenarnya tidak asing bagi kita karena sudah menjadi bahasa serapan dalam bahasa Indonesia. Dalam Kamus Besar Bahasa Indonesia (KBBI) dijelaskan bahwa dunia disebut sebagai lawan dari kata akhirat dan sebagai tempat hidup manusia sebelum mati, atau dapat berarti bumi yang didiami manusia. $^{23}$

17 Muhammad Jamaluddin al-Fandy, Al-Qur'an Tentang Alam Semesta (Jakarta: Bumi Aksara, 1991), 19-20.

18 'Ali 'Audah, Konkordansi Qur'an: Panduan Kata Dalam Mencari Ayat Al-Quran, Terj. (Bogor: Pustaka Litera Antar Nusa, 1996), 11.

${ }^{19}$ Asharuddin Sahil, Indeks Al-Quran: Panduan Mencari Ayat Al-Quran Berdasarkan Kata Dasarnya (Bandung: Mizan, 1994), 174.

${ }^{20}$ Abū Husayn Aḥmad Ibn Fāris Ibn Zakariyah, Maqāyīs al-Lughah..... Lihat pula Mahmud Yunus, Kamus Arab Indonesia (Jakarta: Hidakarya Agung, 1992), 277.

21 Ibid.

22 Ibn Manzur, Lisān al-'Arab, Vol. II (Kairo: Dār al-Ma'ārif, t.th) 1435-1437. Lihat juga Abū Husayn Ahmad Ibn Fāris Ibn Zakariyah, Mu'jam Maqāyís al-Lughah, 366. Ditambahkan oleh al-Fayruzzabady bahwa دنياء jamaknya, padanannya

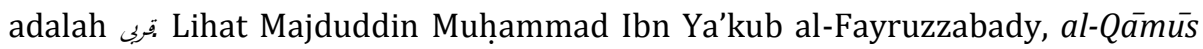
al-Muhitt, Vol IV (Beirut: Dār al-Jail, t.th), 330.

23 JS. Badudu dan Sutan Muhammad Zain, Kamus Umum Bahasa Indonesia, Cet. IV (Jakarta: Pustaka Sinar Harapan, 2000), 363. 
Kehidupan di dunia sifatnya sementara. Dunia merupakan jembatan atau kendaraan menuju kehidupan akhirat yang abadi. Firman Allah QS. al-Ra'd (13): 26:

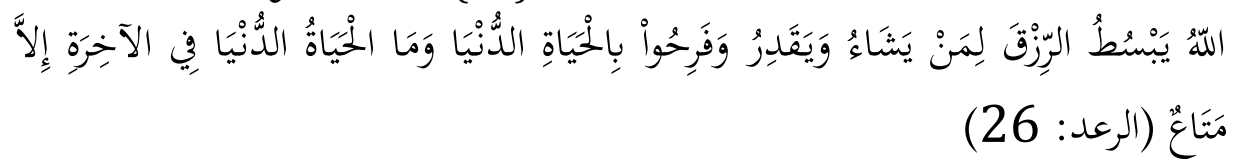

"Allah melapangkan rezki dan menyempitkannya bagi siapa yang Dia kehendaki. Mereka bergembira dengan kehidupan di dunia, padahal kehidupan dunia itu (dibanding dengan) kehidupan akhirat, hanyalah kesenangan (yang sedikit)". ${ }^{24}$

Dengan mengetahui eksistensi kehidupan di dunia sebagaimana dalam ayat di atas, tentu akan mendorong manusia untuk mempersiapkan bekal (beramal) untuk mempersiapkan kehidupan akhirat kelak yang sifatnya abadi.

\section{$\operatorname{Tanah}(ت)$}

Kata tanah (تراب) dalam al-Qur'an terulang sebanyak 43 kali. ${ }^{25}$ Lazimnya, tanah bersifat asam, netral atau alkalik. Kesuburan tanah secara relatif bergantung kepada tekstur susunan kimia, persediaan air, sifat tanah dan iklim. Pupuk buatan dan penggarapan tanah dapat menambah kesuburan, tetapi pada waktu tertentu akan susut jika kadar organisme dalam tanah tidak dipertahankan.

Faktor utama dalam pertanian adalah tanah. Tanah menghasilkan berbagai kekayaan seperti mineral dan kekayaan bumi lainnya. ${ }^{26}$ Peran tanah dalam kehidupan manusia sangatlah urgen, karena merupakan sumber mata pencaharian melalui pengelolahannya. Oleh karena itu pemberian Allah yang sangat berharga ini patutlah disyukuri dan dijaga.

\section{Tempat Tinggal Manusia (سكن)}

Bumi Allah itu luas, maka apa yang diberikan oleh-Nya hendaknya dimanfaatkan untuk kemaslatan hidup manusia. Firman Allah SWT QS. al-Nisa' (4): 97:

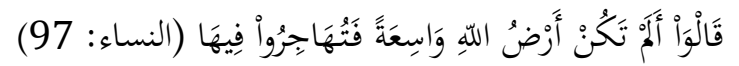

24 Departemen Agama RI, Al-Qur'an dan Terjemahnya ......, 351.

25 Muhammad Fu'ād 'Abd. al-Bāqȳ, al-Mu'jam al-Mufahras Li Alfāz al-Qur'ān alKarìm (t.t.: Maktabah Daḥlān, t.th.), 22 Lihat juga Hassan Shadiliy, Ensiklopedia Indonesia (Jakarta: Ichtiar Baru Van Hoeve, 1984), 34-38.

${ }^{26}$ Hassan Shadiliy, Ensiklopedia Indonesia, 34-38. 
"Para malaikat berkata: Bukankah bumi Allah itu luas, sehingga kamu dapat berhijrah di bumi itu" ${ }^{27}$

Ayat di atas memberikan pemahaman bahwa penciptaan bumi yang luas ini diperuntukkan untuk kemaslahatan hidup manusia. Bumi sebagai tempat untuk berhijrah dalam artian manusia memiliki keluasan untuk berpindah-pindah mencari tempat tinggal dan melangsungkan hidupnya. Manusia bebas berdiam dan beraktifitas di dalamnya. ${ }^{28}$

Menurut Nurcholish Madjid, dengan berdiamnya manusia di bumi ini mereka digugat untuk tidak hanya menetap di satu atau di satu wilayah saja, melainkan mereka harus berpindah-pindah (transmigrasi) untuk berbuat sesuatu dengan tujuan mengangkat harkat dan martabatnya yang diperoleh dari keimanan dan pengabdian kepada Allah SWT. ${ }^{29}$

Bumi diciptakan Allah SWT sebagai tempat tinggal yang cocok bagi perkembangan manusia dengan suhu udara, susunan, kondisi fisik, jarak yang jauh dari matahari dan bulan, peredaran yang mengelilingi matahari, kecondongan kepada poros, kecepatan putaran dan hal-hal lain yang menjadikannya sangat kondusif bagi kehidupan manusia. Firman Allah SWT QS. al-A'rāf (7): 10:

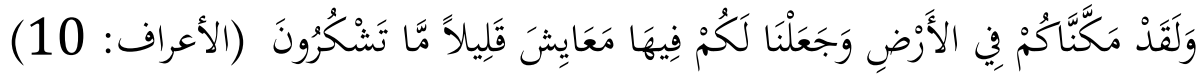

"Sesungguhnya Kami telah menempatkan kamu sekalian di muka bumi dan Kami adakan bagimu di muka bumi (sumber) penghidupan. Amat sedikitlah kamu bersyukur". ${ }^{30}$

Firman Allah SWT yang lain dalam QS. al-Mu'min (40): 64:

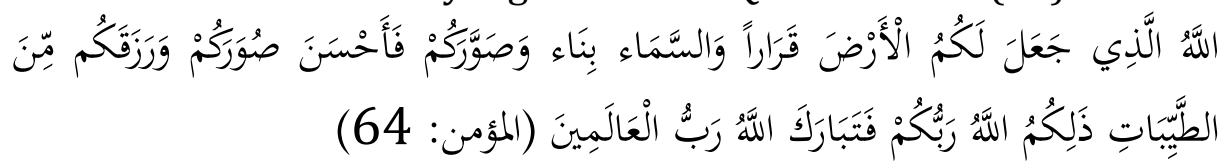

"Allah-lah yang menjadikan bumi bagi kamu tempat menetap dan langit sebagai atap, dan membentuk kamu lalu membaguskan rupamu serta memberi kamu rezki dengan sebahagian yang baik-

27 Departemen Agama RI, Al-Qur'an dan Terjemahnya ......, 194.

${ }^{28}$ Buya Hamka, Tafsir al-Azhar, Cet. II, Vol. V (Jakarta: Pustaka Panjimas, 1992), 222.

29 Nurcholish Madjid, Pintu-Pintu Menuju Tuhan (Jakarta: Paramadina, 1994), 106.

${ }^{30}$ Departemen Agama RI, Al-Qur'an dan Terjemahnya ......., 253. 
baik. Yang demikian itu adalah Allah Tuhanmu, Maha Agung Allah, Tuhan semesta alam". ${ }^{31}$

Quraish Shihab mengatakan dalam tafsirnya:

"Allah yang menjadikan - pada dasarnya buat kamu wahai manusia - bumi dalam keadaan stabil, sehingga dapat menjadi hamparan dan tempat menetap yang layak buat kehidupan, walau dia senantiasa bereda. Menjadikan langit sebagai bangunan yang kukuh berbentuk kubah yang melindungi kamu, walau dia tanpa tiang yang kamu lihat. Membentuk rupa dan postur kamu dalam aneka bentuk yang berbeda satu dengan yang lain. Membaguskan bentuk dan rupa kamu itu sehingga menimbulkan simpati dan daya tarik bagi kamu dan lawan jenis kamu, serta member kamu rezeki yang baik-baik dan bermanfaat". ${ }^{32}$

\section{Kajian Al-Samāwāt (langit) dalam Al-Quran}

Kata السماوات (al-sama-wat) merupakan bentuk plural dari kata (al-sama’) yang berarti langit. Dalam al-Qur'an, kata ini terulang sebanyak 310 kali yang semuanya tersebar dalam beberapa surat di dalam al-Qur'an. Penyebutan dalam bentuk singular (مفرد) sebanyak 120 kali dan bentuk plural (مع) sebanyak 190 kali. $^{33}$ Menurut KBBI, langit berarti yang terbentang di atas bumi, tempat bintang-bintang, tenda pada tempat tidur, papan yang terbentang di atas bilik, kamar di bawah atap, bagian rongga mulut bagian atas. Sedangkan menurut istilah ilmu pengetahuan langit adalah segala sesuatu yang ada di sekeliling benda-benda yang terdiri dari bintang-bintang dan tata surya. Dengan kata lain langit merupakan bagian atas dari permukaan bumi dan memiliki lapisan tersendiri yang disebut atmosfer.

Tentang langit telah diungkap banyak dalam al-Qur'an dengan istilah سماء (singular) atau (plural). Langit bukanlah ruangan kosong tanpa isi. Tempat-tempat kosong di antara bintang-bintang tersebut sebenarnya penuh dengan perantara ajaib yang di luar kemampuan manusia untuk menghitungnya.

31 Ibid, 574.

32 M. Quraish Shihab, Tafsir al-Misbah: Pesan, Kesan dan Keserasian al-Qur'an (Jakarta: Lentera Hati, 2002).

33 Muhammad Nur Ichwan, Tafsir Ilmy: Memahami Al-Qur'an Melalui Pendekatan Sains Modern (Jogjakarta: Menara Kudus, 2004), 188-189. 
Benda langit yang beraneka ragam bergerak dengan teratur, seimbang dan tidak saling menyalahi sedikit pun. Pengaturan benda-benda langit yang disebut dalam al-Qur'an pada intinya merupakan sistem tata surya, tetapi juga memberikan isyarat terhadap benda-benda langit lainnya yang menggunakan sistem tersendiri. Hal ini diungkap dalam Q.S. al-Anbiya' (21): 33:

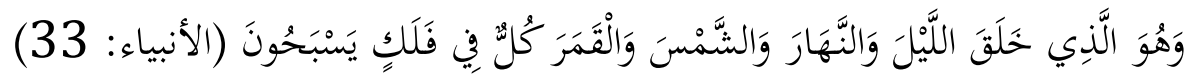

"Dan Dialah yang telab mendptakan malam dan siang, matahari dan bulan, masing-masing dafi keduanya itu beredar di dalam garis edarnya". ${ }^{34}$

Kemudian pada ayat yang lain Q.S. Yāsỉn (36): 40:

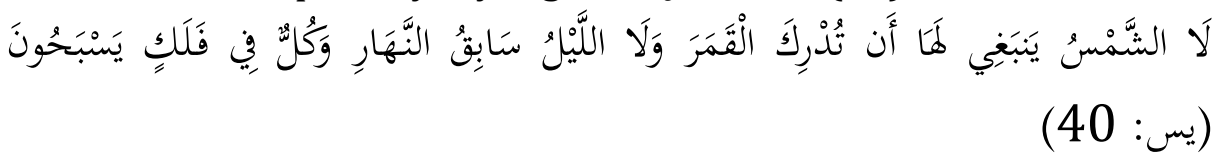

"Tidaklah mungkin bagi matahari mendapatkan bulan dan malam pun tidak dapat mendahului siang. Masing-masing beredar pada garis edarnya". 35

Ayat ini memberikan isyarat kepada kita bahwa betapa teratur dan seimbangnya benda langit sehingga tidak akan terjadi benturan antara satu dengan yang lainnya. Menurut perhitungan, jika suatu benda langit menyimpang sedikit saja dari orbitnya, maka akan mengakibatkan hancurnya sistem tersebut. Misalnya, orbit bumi menyimpang sedikit saja dalam orde $\mathrm{mm}$ lebih besar dari atau lebih kecil dari yang seharusnya. Saat berevolusi memutari matahari, bumi mengikuri orbit yang berdeviasi (menyimpang) sebesar 2,8 $\mathrm{mm}$ dari lintasannya setiap $29 \mathrm{~km}$. Jika penyimpangannya lebih besar sedikit saja dari 2,8 $\mathrm{mm}$, maka orbit bumi akan semakin luas dan kita akan membeku. Selain itu, gaya sentripetal yang diakibatkan oleh gravitasi matahari akan mengecil dan mengakibatkan kecepatan gerak yang lebih lambat. Sedangkan bila penyimpangannya lebih kecil dari $2,8 \mathrm{~mm}$, maka orbit bumi akan semakin kecil dan gravitasi membesar kita akan hangus dan mati.

\footnotetext{
${ }^{34}$ Departemen Agama RI, Al-Qur'an dan Terjemahnya ......., 424.

35 Ibid, 542.
} 


\section{Kandungan dan Korelasi Ayat-Ayat Tentang al-Samāwat Wa al- Ard}

Untuk mengetahui dan memahami eksistensi al-samāwat dan al-ard menurut al-Qur'an, penulis akan kemukakan beberapa ayat tentang hal ini yang diklasifikasikan kepada ayat-ayat Makkiyah dan Madaniyah, serta kandungan dan korelasi antara ayat-ayat tersebut.

1. Ayat-ayat Makkiyah

a. QS. al-Naml (27): 62, menerangkan bahwa tugas manusia di bumi adalah sebagai khalifah.

b. QS. al-Dhāriyāt (51): 20, menerangkan bahwa eksistensi bumi merupakan indikasi atas kekuasaan Allah SWT.

c. QS. al-Ghāshiyah (88): 20, menerangkan bagaimana bumi itu di-hamparkan.

d. QS. al-Burūj (85): 9, menerangkan bahwa bumi di bawah kekuasaan dan kendali Allah SWT.

Dari keempat ayat di atas, dua di antaranya yang tidak memiliki asbab al-nuzut. ${ }^{36}$ Di dalam al-Qur'an tidak semua ayat-ayat memiliki asbab al-nuzul. ${ }^{37}$ Dalam hal ini QS. al-Dhāriyāt (51): 20 dan QS. al-Ghäshiyah (88): 20 yang memiliki asbab al-nuzul, sedangkan dua lainnya tidak.

2. Ayat-Ayat Madaniyah

a. QS. al-Baqarah (2): 11, terdapat larangan untuk berbuat kerusakan di bumi. Kandungan ayat tersebut, memiliki munāsabah (korelasi) ${ }^{38}$ dengan QS. al-Ra'd (13): 25, QS. alḤijr (15): 19, QS. al-Kahfi (18): 19; QS. Tāhā (20): 53, QS. Qāf

\footnotetext{
${ }^{36}$ Asbāb al-Nuzūl adalah sesuatu yang melatar belakangi turunnya suatu ayat atau lebih, sebagai jawaban terhadap suatu peristiwa atau menceritakan suatu peristiwa, atau menjelaskan hukum yang terdapat dalam peristiwa itu. Lihat Dāwud al-Attāā, Mu'jaz 'Ulūm al-Qur'ān, Terj: Afif Muhammad dan Ahsin Muhammad dengan judul Perspektif Baru Ilmu Al-Quran (Bandung: Pustaka Hidayah, 1994), 127.

37 Demikian pendapat jumhūr al-mufassirin sebagaimana yang dikemukakan Abū Husain Ali Ibn Aḥmad al-Wāhidȳ al-Naisābūrȳ, Asbāb al-Nuzul (Maktabah alHalaby, t.th.), 71.

38 Term munāsabah berasal dari akar kata ناسب - يناسب - مناسبة yang berarti kedekatan. Lihat Lihat al-Tahit Ahmad al-Zāwȳ, al-Tartib al-Qamūs al-Muhit 'Alā Tariq al-Miṣbah al-Munīr Wa Asäs al-Baläghah, Cet. III Vol. IV (Beirut: Dār alFikr, t.th.), 360. Dari aspek terminologi munāsabah al-āyah adalah segi-segi hubungan antara satu kalimat lain dalam satu ayat, antara satu ayat dengan ayat yang lain dalam banyak ayat, atau antara satu ayat dengan surah yang lain. Lihat Mannā' al-Qațtān, Mabahith Fĩ 'Ulüm al-Qur'än (Beirut: Manshūrat Lì al-'Așr alHadith, 1973) , 97.
} 
(50): 7, QS. al-Ma'ārij (70): 14, QS. Nūh (71): 19, QS. alNāzi'āt (79): 30 dan QS. al-Ghāshiyāh (88): 20.

b. QS. al-Baqarah (2): 22, menjelaskan bahwa bumi dihamparkan. Kandungannya ayat ini memiliki munasabah dengan QS. al-Ghāshiyah (88): 20 yang tergolong ayat Makkiyah.

c. QS. al-Baqarah (2): 27, menerangkan bahwa orang-orang yang berbuat kerusakan di bumi termasuk orang-orang yang merugi. Kandungan ayat ini memiliki munāsabah dengan penjelasan ayat QS. al-Ghāshiyah (88): 20.

d. QS. al-Baqarah (2): 30, menerangkan peran manusia sebagai khalifah di bumi. Ayat ini bermunāsabah dengan QS. al-Naml (27): 62 yang tergolong ayat Makkiyah.

e. QS. al-Baqarah (2): 33, menerangkan bahwa semua rahasia penciptaan di bumi hanya Allah SWT yang mengetahuinya. Kandungannya, memiliki munāsabah dengan QS. Ali 'Imrān (3): 29 dan 35, QS. al-Māidah (5): 97, QS. al-Ḥajj (22): 70, QS. al-Ḥujurāt (49): 16 dan 18, QS. Qāf (50): 4, QS. al-Mujādalah (58): 7 dan QS. al-Taghābun (64): 4.

f. QS. al-Baqarah (2): 36, menjelaskan bumi merupakan tempat kediaman yang dipenuhi dengan kesenangan. Kandungan ayat ini memiliki munāsabah dengan QS. al-A'rāf (7): 10 dan 24.

g. QS. al-Baqarah (2): 107, menjelaskan bahwa bumi adalah milik Allah SWT. Kandungan ayat tersebut memiliki bermunāsabah dengan QS. Ali-'Imrān (3): 109, 129, 180 dan 189, QS. al-Nisā (4): 126, 131, 132, 170 dan 171, QS. alMāidah (5): 17, 18 dan 40, QS. al-An'ām (6): 12, QS. alTaubah (9): 116, QS. Yūnus (10): 55, 66 dan 68 QS. Hūd (11): 123; Tāha (20): 6, QS. al-Anbiya' (21): 19, QS. alMu'minūn (23): 84, QS. al-Nūr (42): 12 dan 13, QS. alZukhrūf (43): 82 dan 85; QS. al-Jâtsiyah (45): 27, QS. al-Fath (48): 4, 7 dan 14, QS. al-Najm (53): 31, QS. al-Hadid (57): 2 dan 5; QS. al-Munāfiqūn (63): 7, dan QS. al-Burūj (85): 9.

h. QS. al-Baqarah (2): 164, menerangkan bahwa tanda-tanda kehidupan di bumi disebabkan hujan yang turun dari langit. Kandungannya memiliki munasabat dengan QS. Yūnus (10): 24, al-Nahl (16): 65, QS. al-'Ankabūt (29): 63 dan QS. alHadid (57): 17.

i. QS. al-Baqarah (2): 168, menerangkan bahwa isi bumi dipenuhi dengan makanan yang lezat dan manusia diperintahkan untuk mengkonsumsi yang halal. Makanan 
yang lezat tetapi haram, misalnya babi sebagai-mana dalam QS. al-Baqarah (2): 173, QS. al-Māidah (5): 3 al-An'ām (6): 45 dan QS. al-Nahl (16): 115.

j. QS. Âli Imrân (3): 190, menerangkan bahwa rotasi bumi yang mengelilingi matahari menyebabkan adanya pergantian siang dan malam. Kandungannya ayat ini memiliki munāsabat dengan QS. an-Naml (6): 75, QS. Yūsuf (12): 105, QS. Fușsilat (41):39 dan QS. al-Shūrā (42): 31.

k. QS. Ali 'Imrān (3): 133, menerangkan bahwa bumi sangat luas. Kandungannya memiliki munassabat dengan QS. Hū (11):108 dan QS. al-Anbiya' (21): 105.

l. QS. al-Māidah (5): 97, menerangkan bahwa manusia leluasa untuk berhijrah dari satu tempat ke tempat yang lain, karena bumi diciptakan luas. Kandungannya ayat tersebut bermunāsabah dengan QS. Hūu (11):108 dan QS. al-Anbiya' (21): 105.

Al-Qur'an menyebutkan penciptaan tujuh lapis langit dalam berbagai konteks dan peristiwa. Hanya saja kita benar-benar belum mengerti apa sesungguhnya dari "tujuh langit" itu, apakah angka "tujuh" itu menunjukkan fakta tentang jumlah numerik "langit" ataukah angka itu merujuk pada kenyataan "banyak"-nya langit. ${ }^{39}$

Kenyataannya, al-Qur'an memang menggunakan angkaangka untuk menunjukkan banyaknya jumlah sesuatu. Lalu, apakah pengertian yang terkandung di dalam kata "langit" itu? Apakah ia menunjukkan adanya "tujuh alam semesta" ataukah "tujuh galaksi"? Bagaimanapun juga, angka "tujuh" menggambarkan sebuah gagasan tentang kemajemukan, kemahaluasan dan ketidakbatasan ciptaan Allah. ${ }^{40}$

Sisi lain yang dapat kita amati dalam ciptaan Allah SWT adalah tentang sebuah proporsi dan keseimbangan yang sedemikian hebat yang amat jelas tampak dalam keseluruhan alam semesta. Di sana terdapat makna kesatuan, ketunggalan dan keseimbangan dalam keseluruhan (keanekaragaman) semesta raya, semuanya menunjukkan ketunggalan hukum Allah yang dipatuhi seluruh alam.

\section{Kesimpulan}

39 Afzalur Rahman, Ensiklopediana Ilmu Dalam Al-Qur'an, Terj: Taufik Rahman (Bandung: PT Mizan Pustaka, 2007), 68. 40 Ibid. 
Al-Qur'an secara teks tidak berubah, tetapi penafsiran atas teks, selalu berubah, sesuai dengan konteks ruang dan waktu manusia. Karenanya, al-Qur'an selalu membuka diri untuk dianalisis, dipersepsi dan diinterpretasikan (ditafsirkan) dengan berbagai alat, metode, dan pendekatan untuk menguak isi sejatinya. Aneka metode dan tafsir diajukan sebagai jalan untuk membedah makna terdalam dari al-Qur'an itu.

Penafsiran baru yang dimaksud merupakan perasaan adanya keperluan untuk melakukan upaya-upaya pembaruan dan penyesuaian dalam penafsiran al-Qur'an dengan menggunakan pendekatan-pendekatan baru yang lebih baik. Usaha ini merupakan upaya memahami ayat-ayat al-Qur'an dengan konteksnya, yaitu situasi dan permasalahan masa kini.

\section{Daftar Pustaka}

Assad, Muhammad. The Message of the Qur'an. Gibraltar: Dār alMaktab, 1980.

'Aț̣ār (al), Dāwud, Mu'jaz 'Ulūm al-Qur'an, terj: Afif Muhammad dan Ahsin Muhammad dengan judul Perspektif Baru Ilmu AlQuran. Bandung: Pustaka Hidayah, 1994.

'Audah, 'Ali. Konkordansi Qur'an: Panduan Kata Dalam Mencari Ayat Al-Quran, terj. Bogor: Pustaka Litera Antar Nusa, 1996.

Badudu, JS. dan Zain, Sutan Muhammad. Kamus Umum Bahasa Indonesia, Cet. IV. Jakarta: Pustaka Sinar Harapan, 2000.

Bāqȳ (al), Muhammad Fu'ād 'Abd. al-Mu'jam al-Mufahras Li Alfāz alQur'an al-Karim. t.t.: Maktabah Daḥlān, t.th.

Fandy (al), Muhammad Jamaluddin. Al-Qur'an Tentang Alam Semesta. Jakarta: Bumi Aksara, 1991.

Fayrūzābādȳ (al), Majduddin Muhammad Ibn Ya'qūb. al-Qāmūs alMuhịt, Vol IV. Beirut: Dār al-Jail, t.th.

Habsyi (al), Hussin. Kamus al-Kauthar Lengkap Arab-Indonesia, Cet. III. Surabaya: Yayasan Pesantren, t.th.

Hamka, Buya. Tafsir al-Azhar, Cet. II, Vol. V. Jakarta: Pustaka Panjimas, 1992.

HS., Fachruddin. Ensiklopedia Al-Quran, Cet. I, Vol. I. Jakarta: Rineka Cipta, 1952.

Ichwan, Muhammad Nur. Tafsir Ilmy: Memahami Al-Qur'an Melalui Pendekatan Sains Modern. Jogjakarta: Menara Kudus, 2004. 
Ma'arif, Ahmad Syafi'ie. "Posisi Sentral Al-Qur'an dalam Studi Islam", dalam Metodologi Penelitian Agama, ed. Taufik Abdullah dan M. Rusli Karim. Yogyakarta: PT. Wacana Yogya, 1989.

Madjid, Nurcholish. Pintu-Pintu Menuju Tuhan. Jakarta: Paramadina, 1994.

Manẓur (Ibn). Lisān al-'Arab, Vol. II. Kairo: Dār al-Ma'ārif, t.th.

Munawwir, Ahmad Warson. Kamus Al-Munawwir Arab Indonesia Terlengkap. Yogyakarta: Pustaka Pesantren, 1984.

Mustaqim, Abdul. Pergeseran Epistemologi Tafsir. Yogyakarta: Pustaka Pelajar, 2008.

Naisābūrȳ (al), Abū Husain Ali Ibn Ahmmad al-Wāhidȳ. Asbab alNuzul. Maktabah al-Halaby, t.th.

Nawawi, Hadari. Demi Masa di Bumi dan di Sisi Allah Swt, Cet. I. Yogyakarta: Gadjah Mada University Press, 1995.

Nawawi, Rif'at Syauqi. Rasionalitas Tafsir Muhammad Abduh. Jakarta: Paramadina, 2002.

Poerwadarminta, W.J.S., Kamus Umum Bahasa Indonesia, Cet. I. Jakarta: Balai Pustaka, 1984.

Rahman, Afzalur. Ensiklopediana Ilmu Dalam Al-Qur'an, Terj: Taufik Rahman. Bandung: PT Mizan Pustaka, 2007.

Ramli, Muhammad. Ilmu Alamiah Dasar "Diktat". Ujung Pandang: Fakultas Ushuluddin, 1993.

RI, Departemen Agama. Al-Qur'an dan Terjemahnya. Semarang: Toha Putra, 1983.

Qatțān (al), Mannā'. Mabahith Fì 'Ulūm al-Qur'ann. Beirut: Manshūrat Li al-'Așr al-Hadith, 1973.

Sahil, Asharuddin. Indeks Al-Quran: Panduan Mencari Ayat Al-Quran Berdasarkan Kata Dasarnya. Bandung: Mizan, 1994.

Shadiliy, Hassan. Ensiklopedia Indonesia. Jakarta: Ichtiar Baru Van Hoeve, 1984

Shihab, M. Quraish. Membumikan Al-Qur'an Fungsi dan Peran Wahyu dalam Kehidupan Masyarakat. Bandung: Penerbit Mizan, 1994.

. Tafsir al-Misbah: Pesan, Kesan dan Keserasian al-Qur'an. Jakarta: Lentera Hati, 2002.

Zakariyah (Ibn), Abū Husayn Aḥmad Ibn Fāris. Mu'jam Maqāyis alLughah, Cet. II, Vol. II. Kairo: Musțafā al-Bābȳ al-Halaby, 1971.

Zāwȳ (al), al-Ṭahit Aḥmad. al-Tartib al-Qamūs al-Muhịt 'Alā Taríq alMișbah al-Munír Wa Asas al-Balaghah, Cet. III Vol. IV. Beirut: Dār al-Fikr, t.th. 